\title{
TRANSFER OF BRACHIALIS MUSCLE TO TRICEPS FOR RESTORATION OF ELBOW EXTENSION IN PATIENTS WITH OBSTETRIC PALSY SEQUELAE
}

\author{
DOĞUMSAL BRAKIYAL PLEKSUS PARALIZISI NEDENIYLE DIRSEK EKSTANSIYON \\ KUSURU BULUNAN HASTALARDA BRAKIYALIS TRISEPS TENDON TRANSFERI \\ UYGULANAN OLGULARIN DEĞERLENDIRILMESI
}

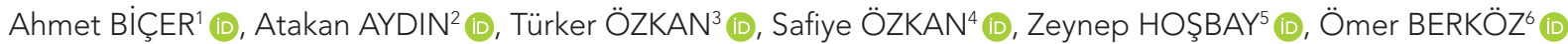 \\ ${ }^{1}$ Ege University, Faculty of Medicine, Department of Plastic, Reconstructive, and Aesthetic Surgery, Izmir, Turkey \\ 2INORA (Istanbul Neuro-Orthopaedics) Group, Istanbul, Turkey \\ 3Private Practice, Istanbul, Turkey \\ ${ }^{4}$ Bahçeşehir University, Faculty of Health Sciences, Department of Physiotherapy and Rehabilitation, Istanbul, Turkey \\ ${ }^{5}$ Biruni University, Faculty of Health Sciences, Department of Physiotherapy and Rehabilitation, Istanbul, Turkey \\ ${ }^{6}$ Istanbul University, Istanbul Faculty of Medicine, Department of Plastic, Reconstructive, and Aesthetic Surgery, Division of Hand \\ Surgery, Istanbul, Turkey
}

ORCID IDs of the authors: A.B. 0000-0001-5157-7350; A.A. 0000-0002-3568-3513; T.Ö. 0000-0003-4035-843X; S.Ö. 0000-0001-8051-1502; Z.H. 0000-0003-1530-2880; Ö.B. 0000-0001-8063-9995

Cite this article as: Bicer A, Aydin A, Ozkan T, Ozkan S, Hosbay Z, Berkoz O. Transfer of brachialis muscle to triceps for restoration of elbow extension in patients with obstetric palsy sequelae. J Ist Faculty Med. Published online February 7, 2022. doi: 10.26650/IUITFD.1035427

\section{ABSTRACT}

Objective: Elbow extension deficit following brachial plexus injuries can sometimes be overlooked. Elbow flexion deficit is more prominent in the early stages of obstetric paralysis and is used as an indication for early nerve surgery. However, in the future extension deficits may become more numerous.

Residual disabilities following obstetric paralyses can be dynamically addressed by tendon transfers. In patients with obstetric paralysis, canonical donor muscles such as the deltoid or biceps may be insufficient for restoration of elbow extension. The brachialis muscle, because of its deep and secluded position, may be considered as one of the more recent options for selection as a donor in these patient groups.

In this study, the efficiency of brachialis to triceps transfer both in elbow extension and in shoulder abduction was assessed.

Materials and Methods: Seven obstetrical palsy patients with varying degrees of sequelae around the shoulder and elbow underwent a brachialis to triceps transfer procedure. All patients had previously undergone a modified Hoffer procedure. Ranges of motion in shoulder and elbow joints were recorded before

\section{ÖZET}

Amaç: Brakiyal pleksus yaralanmaları sonrası dirsek ekstansiyonu sorunları genellikle ön planda tutulmaz. Obstetrik paralizinin erken evrelerinde dirsek fleksiyon kusurları ön plandadır ve erken dönem sinir cerrahisi endikasyonu için klinik bir belirteç olarak kullanılır. Yıllar geçtikçe fleksiyon işlevinin geri kazanımıyla birlikte dirsekte ekstansiyon kayıpları ön plana çıkabilir.

Tendon transferleri obstetrik paralizi sekellerinin geç dönem dinamik rekonstrüktif tedavi seçenekleri arasında yer almaktadır. Obstetrik paralizili hastalarda deltoid ve biseps gibi klasik donörlerin güçleri dirsek ekstansiyonunu sağlamaya yetmeyebilir. Brakiyalis kası, kolda derin yerleşimiyle gizli bir alternatif olabilir. Bu çalışmada dirsek ekstansiyon kusuru sekeli bulunan obstetrik paralizi hastalarında brakiyalis triseps tendon transferinin dirsek ekstansiyonu ve omuz ekstansiyonu üzerine etkileri incelenmiştir.

Gereç ve Yöntem: Çalışmaya dirsek ve omuz eklemleri çevresinde sekelleri bulunan ve bu amaçla brakiyalis triseps tendon transferi uygulanmış yedi obstetrik paralizi hastası dâhil edilmiştir. Tüm hastalara daha öncesinde modifiye Hoffer prosedürü uygulanmıştı. Hastalarda omuz ve dirsek aktif ve pasif eklem hareket

Corresponding author/iletişim kurulacak yazar: ahmet.bicer@gmail.com

Submitted/Başvuru: 11.12.2021 • Revision Requested/Revizyon Talebi: 30.12.2021 •

Last Revision Received/Son Revizyon: 14.01.2022 • Accepted/Kabul: 14.01.2022 • Published Online/Online Yayın: 07.02.2022 
and after the transfer. A minimum of $\mathrm{M} 3+$ in elbow flexion was set as a prerequisite for the transfer.

Results: The elbow extension was improved from a median of $-70^{\circ}$ (interquertile range, IQR: $20^{\circ}$ ) to a median of $-10^{\circ}$ (IQR: $35^{\circ}$ ) in the follow-up $(p<0.05)$. Shoulder abduction was improved from a median of $140^{\circ}\left(\right.$ IQR: $5^{\circ}$ ) to a median of $170^{\circ}$ (IQR: $15^{\circ}$ ) $(p<0.05)$. Elbow flexion power was found to be diminished from median M4 (Q1: M3+, Q3: M5) to M3 (Q1: M3, Q3: M3+) $(p<0.05)$

Conclusions: Brachialis to triceps transfer was found to be a suitable alternative in palliative surgery of obstetric palsy patients in terms of elbow extension. Loss of elbow flexion power was within acceptable range.

Keywords: Tendon transfer, obstetric paralysis, elbow joint, shoulder joint açıklıkları gonyometrik olarak analiz edildi. Brakiyalis transferi, minimum dirsek fleksiyon gücü M3+ olan hastalara uygulandı.

Bulgular: Dirsek ekstansiyonu ameliyat öncesi ortanca $-70^{\circ}$ (interkuartil açıklık, IQR: $\left.10^{\circ}\right)^{\prime}$ den ameliyat sonrası izlemde ortanca $-10^{\circ}$ (IQR: $\left.35^{\circ}\right)^{\prime}$ ye çıkmıştır $(p<0,05)$. Omuz abdüksiyonu ise ameliyat öncesi ortanca $140^{\circ}\left(\text { IQR: } 5^{\circ}\right)^{\prime}$ den ameliyat sonrası izlemde ortanca $170^{\circ}\left(I Q R: 15^{\circ}\right)^{\prime}$ ye çıkmıştır $(p<0,05)$. Dirsek fleksiyonu ise ameliyat öncesi ortanca M4 (IQR: M3+, M5)'den, ameliyat sonrası ortanca M3 (IQR: M3, M3+)'e gerilemiştir $(p<0,05)$.

Sonuç: Brakiyalis triseps transferi obstetrik paralizi sekeli bulunan olgularda dirsek ekstansiyonunu sağlamak için geçerli bir seçenek olarak ortaya konmuştur. Bununla birlikte dirsek fleksiyonunda istatistiki olarak anlamlı bir kayıp gözlenmektedir. Bu kayıp klinik olarak kabul edilebilir düzeylerdedir.

Anahtar Kelimeler: Tendon transferi, obstetrik paralizi, dirsek eklemi, omuz eklemi

\section{INTRODUCTION}

Functional recovery of the affected limb is the main goal in the treatment of neonatal or obstetric brachial plexus palsy. The term obstetric palsy refers to a clinical condition proposed to result from an antenatal injury to immature brachial plexus including nerve roots, and/or their branches. Although rare (0.06 to $0.26 \%)$, the disease is known to cause significant morbidity in the affected population. At least 10 to 30 percent of cases do not achieve complete recovery $(1-3,4)$.

Various options for treatment of obstetric plexus lesions are available, ranging from hand therapy, direct and indirect neural repair, and surgical interventions addressing the sequelae of the primary lesion which include permanent loss of muscle strength, joint, ligamentous, or bone abnormalities (5).

In the natural course of the disease, many infants show excellent recovery with a full active range of motion in all joints. Some end up with little to moderate disability, predominantly in the upper roots. In rare examples, a devastating flaccid limb with marked disability can be the outcome $(4,6)$.

The wide range of severity level in disease presentation is further complicated by the diversity of affected muscle groups and age of the patient at presentation. However, some patterns are more prominent in older age groups such as lack of shoulder abduction (6). The age and problem-based clinical approach to an obstetrical brachial plexus injury patient in our institution is schematized in detail in Figure 1.

The importance of elbow extension following traumatic or obstetric injuries of the brachial plexus is at times understated and has been studied less than elbow flexion (7). The most probable explanation for this may be the contribution of gravity to passive extension of the elbows in the standing position. However, when the shoulder is abducted, raising the hand over the head requires a certain extent of elbow extensionto assure joint stabilization (8).

As most patients with paralytic plexus injury sequelae present with weakness in elbow flexion, a flexion contracture may be seen as a paradoxical outcome (9). However, restoration of elbow extension is an integral part of upper extremity surgical reconstructions. Improvements in completing daily activities such as lowering an object from above, handwriting, steering a wheelchair, driving a car and swimming depend on restoration of elbow extension function (10).

An elbow flexion contracture can be addressed by z-lengthening of the biceps tendon, release of lacertus fibrosus, and brachialis, as well as joint capsule (9). Some reconstructive options previously put forth for elbow extension have stood the effects of time. Examples are transfer of the posterior head of deltoid muscle to triceps (Moberg procedure), and transfer of the biceps to triceps (Friedenberg procedure) $(11,12)$. However, if those motors are also paralyzed (as is the case with most obstetric paralysis patients), alternative methods of elbow extension restoration become more important (8). However, literature is scarce on this subject (13). Some newer approaches, like the transpositional transfer of brachioradialis to triceps (14), and more recently, transfer of lower trapezius for elbow extension have been suggested (13).

Transfers of the brachialis muscle, with its fairly consistent anatomic location deep in the arm may have some advantages, such as sparing other muscles for further transfers with less morbidity $(13,15)$.

In their cross-sectional study of patients with various elbow problems, Chuang et al. included 10 patients who had been treated with a brachialis to triceps tendon transfer, and four more who had been treated with trans- 


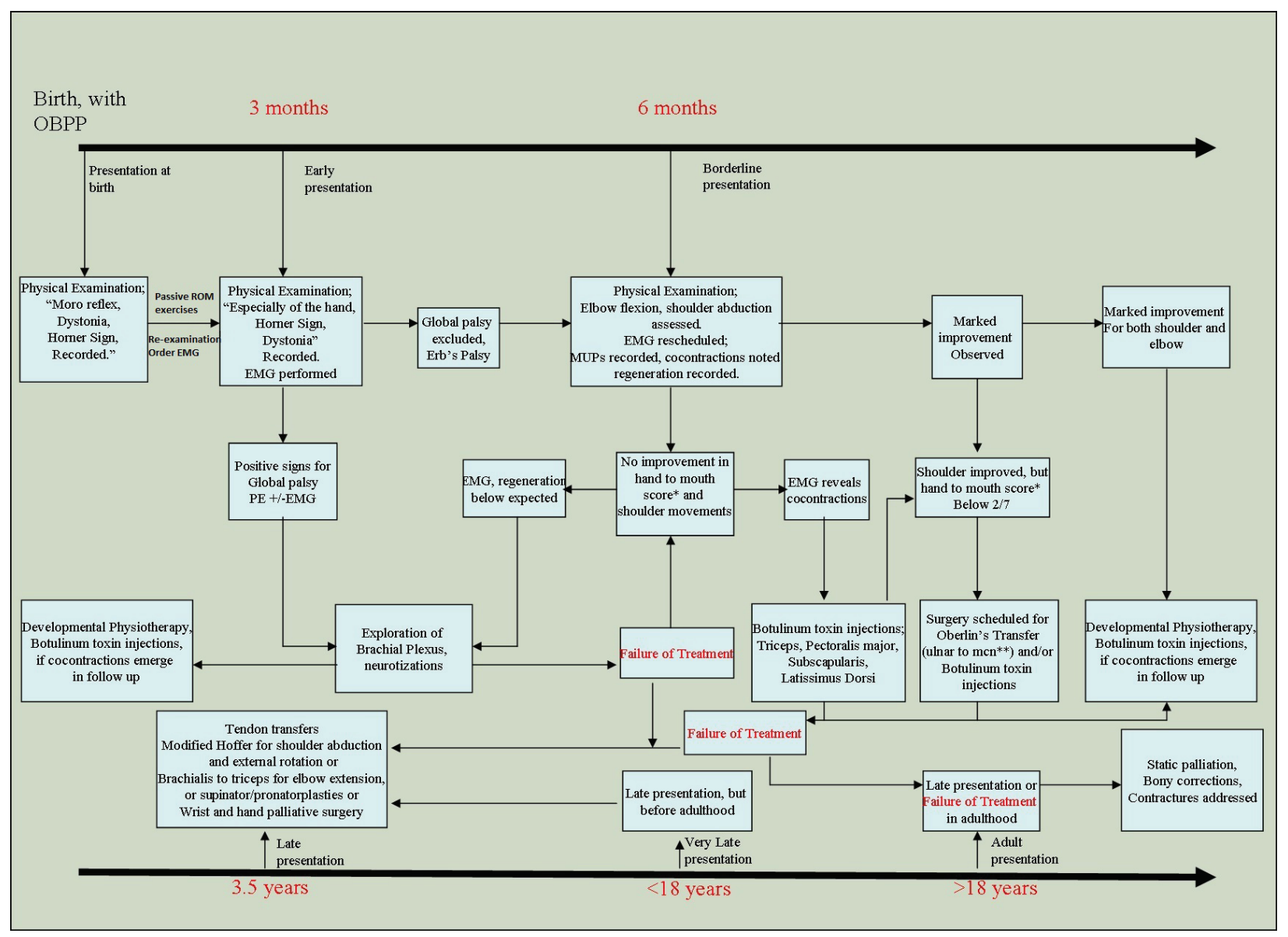

Figure 1: Clinical decision-making progress regarding obstetric brachial plexus palsy patients in our institution

*: A score of four less in the muscle grading system of the Hospital for Sick Children. Lack of elbow flexion against gravity.

**: Partial ulnar nerve transfer to musculocutanous nerve. "mcn", musculocutanous nerve.

fer of both biceps and brachialis (16). However, half of those patients (in both approaches) needed a secondary free vascularized muscle transfer for restoration of elbow flexion (16).

In this study, to restore elbow extension, a brachialis to triceps tendon transfer was performed in seven cases with obstetrical palsy sequelae that had abduction and external rotation deficit in their shoulders and extension deficit in their elbows. All of the patients had previously undergone a latissimus dorsi and teres major transfer to address the deficit in shoulder abduction and external rotation.

\section{MATERIALS AND METHODS}

This retrospective case study was approved by Istanbul University, Istanbul Medical Faculty, Ethical Committee for Clinical Research, filed with date and number: 30.11.2021-613417.

This study was conducted in a retrospective fashion. The authors declare that the operative techniques used are scientifically proven and just. The authors also declare that they have read the World Medical Association's Declaration of Helsinki (1964) including its $6^{\text {th }}$ revision (2008) and that this study follows the declaration.

Seven global obstetrical palsy patients with varying degrees of sequelae around shoulder and elbow underwent a brachialis to triceps transfer procedure in our clinic over a two-year period were included. The median age at the time of operation was 6 years, IQR: 10 ( $\mathrm{min} / \mathrm{max}, 5 / 16)$. All the patients had previously undergone a latissimus dorsi and teres major to greater tubercle of the humerus transfer to improve the shoulder abduction and external rotation with a lapse of two years. Lack of elbow extension against gravity was the indication for the transfer.

\section{Preoperative and postoperative assessments}

Active ranges of motion in shoulder and elbow joints, as well as passive ranges of motion in the affected joints (to omit established contractures) were recorded with goniometric analyses by the physiotherapy team in the presence 
of the surgical team before the brachialis transfer (after the latissimus dorsi/teres major transfer). The motor capacity of the brachialis muscle was graded according to the British Medical Council (BMC) muscle grading system with modifications made by Terzis et al. (17). A minimum of $\mathrm{M} 3+$ in elbow flexion was set as a prerequisite for the transfer.

Active ranges of motion in the joints were assessed with goniometric analyses by the physiotherapeutic team in the presence of the surgical team. Elbow flexion capacity was assessed according to the BMC grading system to note the extent of loss after the transfer.

\section{Surgical technique}

The brachialis muscle was dissected through an anterior elbow crease incision preserving the biceps tendon. A careful dissection should be carried out from there on; as medial to the tendon lies the median nerve and brachial artery and lateral to the tendon lies the radial nerve. The distal 1/3 of the brachialis muscle was dissected free after detachment from its insertion at the ulnar bone and transferred posteriorly and laterally to the olecranon area through a subcutaneous tunnel. Another incision was made dorsally at the olecranon area to dissect the distal portion of the triceps tendon. The transferred brachialis muscle tendon was interwoven to the triceps tendon in an end-to-side fashion.

After closure, cast immobilization was applied while the elbow was fully extended. After the operation and a four week period of cast immobilization, physical therapy was initiated with an isolated passive range of motion exercises and splinting until the sixth week. Re-education exercises and electrical stimulation were started at the sixth postoperative week, gentle resistive exercises were initiated between the $8^{\text {th }}$ and $12^{\text {th }}$ weeks and resistive exercises were begun at the $12^{\text {th }}$ week (Figures 2,3 ).

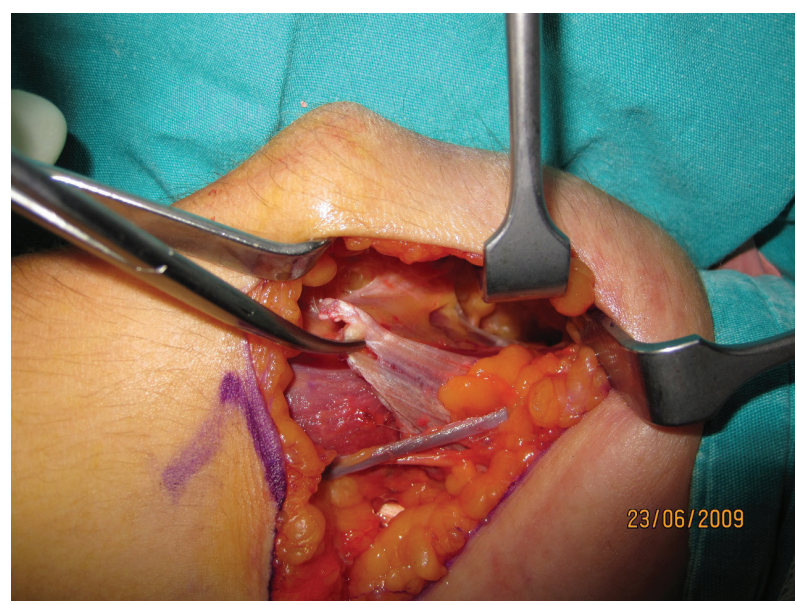

Figure 2: A sufficient excursion of the brachialis muscle is assured before transfer of the muscle laterally and posteriorly to the olecranon region

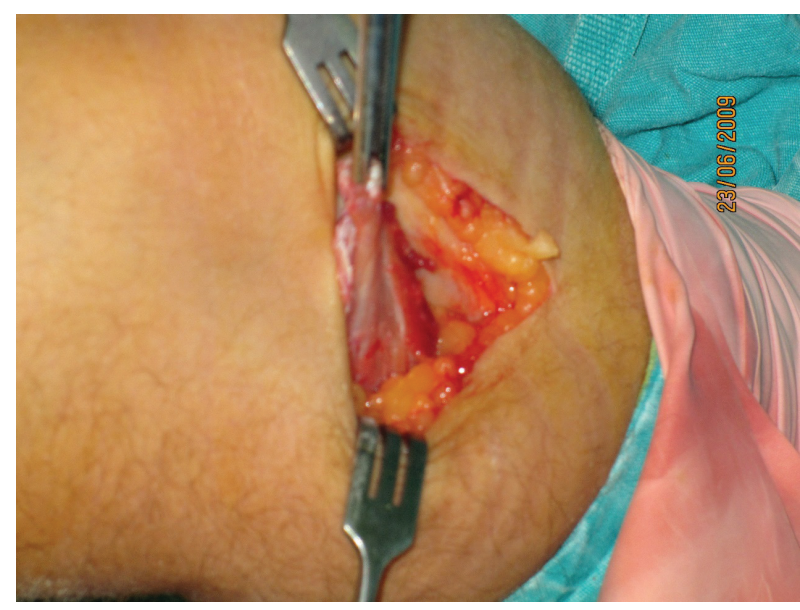

Figure 3: A posterior incision is made above olecranon to visualize the insertion of the triceps tendon. Brachialis tendon is delivered to this incision through a subcutaneous tunnel

\section{Statistical analyses}

Statistical analyses were performed using SPSS v. 18.0 (IBM Corp., Armonk, NY, USA). The quantitative assessment of the acquired data was made via descriptive statistics. The changes in elbow extension, shoulder abduction or elbow flexion with surgical intervention were tested by Wilcoxon signed-rank test with a p-value adjusted at 0.05 .

\section{RESULTS}

Median follow-up was 12 months, IQR: 17 (min/max, 6/23 months). The elbow extension improved from a median of $-70^{\circ}$, IQR: $20^{\circ}\left(\mathrm{min} / \mathrm{max},-90^{\circ} /-40^{\circ}\right.$; here $0^{\circ}$ means full elbow extension while minus degrees dictate extension deficit) to a median of $-10^{\circ} 10 R: 35^{\circ}\left(\mathrm{min} / \mathrm{max},-40^{\circ} / 0^{\circ}\right)$. The improvement in elbow extension was found to be statistically significant $(p<0.05)$. Shoulder abduction was improved significantly $(p<0.05)$ from a median of $140^{\circ}$ IQR: $5^{\circ}\left(\mathrm{min} / \max , 135^{\circ} / 150^{\circ}\right)$ to a median of $170^{\circ}$ IQR: $15^{\circ}$ $\left(\min / \max , 165^{\circ} / 180^{\circ}\right)$ (Figure 4).

Elbow flexion power was found to be diminished from a median M4 (interquartile range, M3+ to M5, BMC grading) to a median M3 (interquartile range, M3 to $M 3+$ ). This downgrading was found to be statistically significant $(p<0.05)$. Hand to mouth activity was preserved. The results are summarized in Table 1.

\section{DISCUSSION}

Since elbow extension is mostly performed passively in daily life and is of secondary importance when compared to elbow flexion, muscle transfer to triceps is not commonly mentioned in the obstetrical palsy literature. The methods to achieve improved elbow extension in 


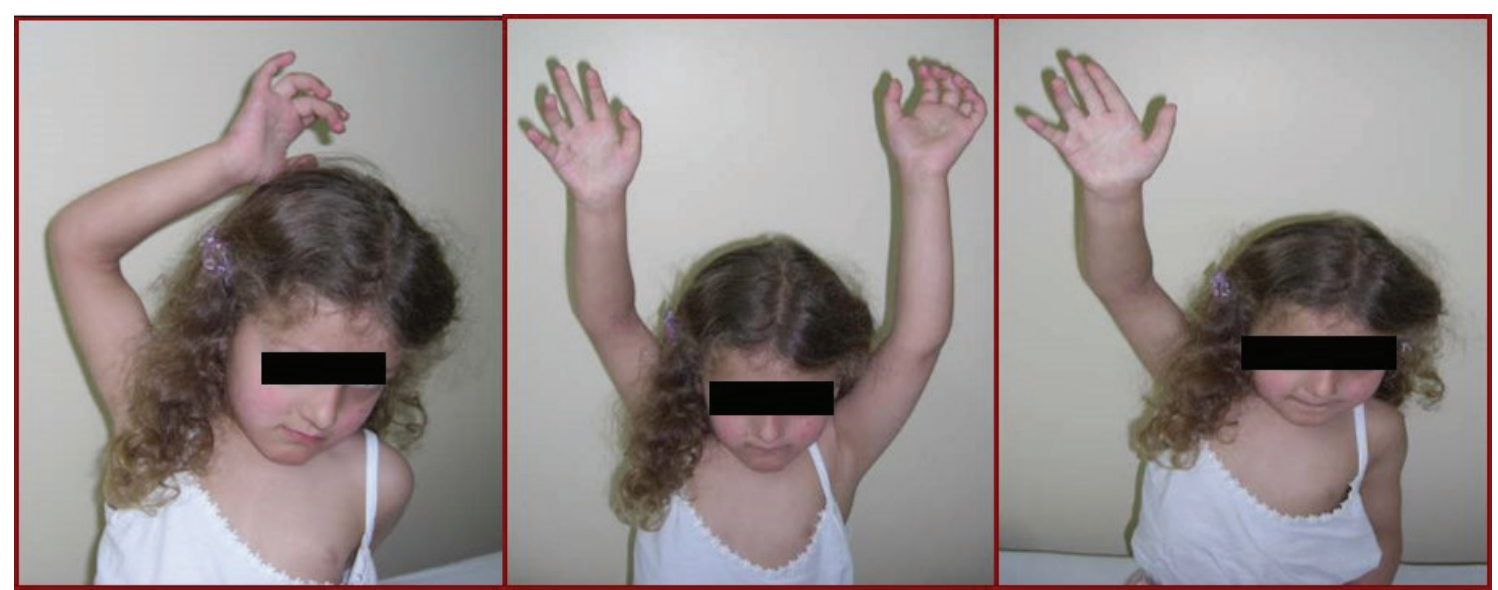

Figure 4: After a brachialis to triceps transfer this patient could achieve an adequate elbow extension and shoulder abduction.

Table 1: Preoperative and postoperative evaluation of the patients that underwent a brachialis to triceps procedure are presented

\begin{tabular}{|c|c|c|c|c|c|c|c|c|c|}
\hline Patients & Age & $\begin{array}{l}\text { Previous } \\
\text { surgery }\end{array}$ & $\begin{array}{l}\text { Follow-up, } \\
\text { months }\end{array}$ & $\begin{array}{l}\text { Preop } \\
\text { active } \\
\text { elbow } \\
\text { extension } \\
\left(^{\circ}\right)\end{array}$ & $\begin{array}{l}\text { Postop } \\
\text { active } \\
\text { elbow } \\
\text { extension } \\
\left(^{\circ}\right)\end{array}$ & $\begin{array}{c}\text { Preop } \\
\text { active } \\
\text { shoulder } \\
\text { abduction }\end{array}$ & $\begin{array}{l}\text { Postop } \\
\text { active } \\
\text { shoulder } \\
\text { abduction }\end{array}$ & $\begin{array}{l}\text { Preop } \\
\text { active } \\
\text { elbow } \\
\text { flexion }\end{array}$ & $\begin{array}{l}\text { Postop } \\
\text { active } \\
\text { elbow } \\
\text { flexion }\end{array}$ \\
\hline 1 & 6 & Yes* & 12 & -80 & -40 & 140 & 170 & M4 & M3+ \\
\hline 2 & 5 & $Y_{e s}^{\star \star}$ & 12 & -70 & -10 & 135 & 160 & M5 & M4 \\
\hline 3 & 6 & Yes* & 23 & -90 & 0 & 145 & 185 & M3+ & M3 \\
\hline 4 & 5 & Yes $^{\star}$ & 23 & -60 & -10 & 140 & 175 & M3 & M3- \\
\hline 5 & 16 & Yes* & 6 & -70 & -35 & 150 & 180 & M4 & M3 \\
\hline 6 & 6 & Yes* & 23 & -40 & 0 & 140 & 170 & M5 & M3 \\
\hline 7 & 15 & Yes $^{\star}$ & 6 & -70 & -8 & 140 & 165 & M4 & M3+ \\
\hline Median & 8.4 & & 15 & -70 & -10 & 140 & 170 & M4 & M3 \\
\hline$P^{* * *}$ & & & & \multicolumn{2}{|c|}{0.018} & \multicolumn{2}{|c|}{0.017} & \multicolumn{2}{|c|}{0.016} \\
\hline
\end{tabular}

*: A modified Hoffer procedure to improve shoulder abduction, **: A modified Hoffer procedure to improve shoulder abduction followed by two Botulinum toxin $A$ injections to subscapularis muscle to improve shoulder external rotation, $* \star \star$ : Wilcoxon Signed Rank Test was used to test the significance of postoperative changes of median values.

patients with obstetric palsy include traditional tendon transfers such as biceps, latissimus dorsi, and posterior deltoid to triceps transfers, free gracilis muscle transfer, biceps/brachialis transfer and lower trapezius transfer $(12,13,16,18,19)$. Brachioradialis muscle transfer was also popularized by our team a while ago, but we prefer to preserve this muscle for future pronatoplasty operations (14).

Utilization of brachialis muscle for transfers around the elbow was first suggested by Chuang, however it was Bertelli who introduced this transfer for elbow extension in a more organized manner $(16,20)$. The rationale behind using brachialis over biceps was the risk of losing elbow flexion power. This particular risk is also present with a brachialis transfer. In our group of patients, there was minimal donor site morbidity both from a functional and a cosmetic point of view. Elbow flexion power diminished significantly (a downgrade from a median M4 to a median M3) but since biceps tendon was preserved, hand to mouth function was not grossly affected. This may occur as a surprising outcome as the brachialis muscle has a slightly greater physiological cross-sectional area (PCSA) than biceps brachii $\left(5.4 \mathrm{~cm}^{2}\right.$ and $5.1 \mathrm{~cm}^{2}$, respectively). However, isometric moment-generating capacity, which is a function of not only PCSA, but also of average 
moment arm and pennation angle is greater for biceps brachii than that for brachialis muscle, excluding the extremes of elbow flexion angles (21). Additionally, an anatomic study conducted by Leonello et al. ensured that brachialis muscle constantly has two separate muscle bellies that may enable a partial transfer (15). By doing so, the risk of losing elbow flexion power may be minimized. Another option for restoration of elbow extension may be distant transfers such as a free gracilis transfer (18). A rather lengthy operative time and adding a considerable technical difficulty, these transfers are mainly suitable for recently paralyzed muscles such as traumatic brachial plexus injuries or early obstetric paralyses. However, some patients (as was the case for patients in this study) are late referrals with obstetric paralyses. With their considerable denervation time, a distant transfer may not be suitable without extraplexal neurotisations, which in turn may result in the loss of precious time before physiotherapy, especially if multiple transfers have been made.

Restoration of shoulder abduction with transfer of latissimus dorsi and teres major has proven successful in our clinic (22). Nevertheless, the lack of elbow extension becomes more obvious after this transfer although shoulder abduction and extension are improved dramatically. Realizing that when an "elbow extension splint" is applied, an improvement in shoulder abduction can be achieved, we decided to perform a tendon transfer to mimic the effects of the splint. Anatomically and physiologically, elbow extension did not augment shoulder abduction. However, it was observed that when a splint extended the elbow, the shoulder abduction was higher. This might be due to better stabilization of the elbow joint. The child may have the opportunity to concentrate solely on the shoulder during abduction (This statement was made by Michael Tonkin during the Asia Pacific Hand Society Meeting at Taiwan 2009) (Figure 5).

Utilization of brachialis muscle for various purposes in the upper extremity is a new concept. Not surprisingly, the first attempts to use this rather secluded and powerful muscle, were made to restore elbow extension $(16,20)$. Chuang et al. reported their results with the transfer of the muscle instead of just releasing it to counteract the powerful elbow flexors in favor of extension, which is not emphasized enough (16). Bertelli, however, carried the concept onwards, describing the technique in detail (20). Our clinic took the next step in utilizing this muscle for various purposes in upper extremity palsies with promising results.

Apart from having been designed in a retrospective fashion, this study has certain limitations, for example, it lacks preoperative and postoperative qualitative measures such as quality of life scores, and functional scores such as the Hospital for Sick Children Scale. Another short-

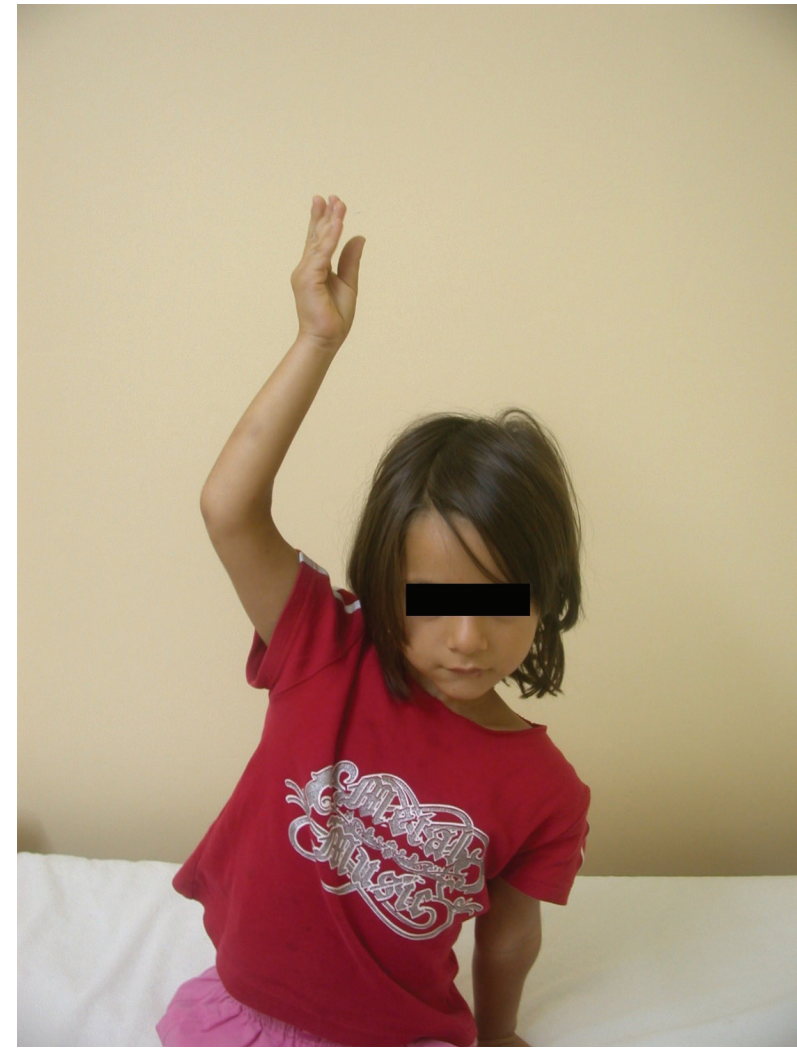

Figure 5: Shoulder abduction and elbow extension were both improved markedly after the triceps transfer. Note that no additional interventions were made for shoulder abduction.

coming may be the lack of electromyographic studies and having a rather small group of patients. Additionally, to obtain solid evidence on the advantage of this technique compared to the alternatives, a comparative study should be conducted to include alternative methods for elbow extension restoration. Statistical differences among these methods in respect to gains in elbow extension as well as loss in elbow flexion or other donor morbidities should be tested.

\section{CONCLUSION}

In selected cases of obstetrical brachial plexus palsy, brachialis tendon transfer to triceps tendon is a promising alternative for restoration of elbow extension, if not, providing elbow stability, which in turn facilitates shoulder abduction.

Informed Consent: Written consent was obtained from the participants.

Ethics Committee Approval: This study was approved by the Clinical Research Ethical Committee of the Istanbul University, Istanbul Faculty of Medicine (Date: 30.11.2021, No: 613417) 
Peer Review: Externally peer-reviewed.

Author Contributions: Conception/Design of Study- A.B., A.A.,T.Ö.; Data Acquisition- S.Ö., Z.H.; Data Analysis/Interpretation- Z.H., A.B.; Drafting Manuscript- A.B.; Critical Revision of Manuscript- Ö.B., A.A., T.Ö.; Approval and Accountability- A.B., A.A., T.Ö., S.Ö., Z.H., Ö.B.

Conflict of Interest: Authors declared no conflict of interest

Financial Disclosure: Authors declared no financial support.

Acknowledgement: The researchers would like to thank Associative Professor Elcil Kaya Biçer for checking fluency of written English.

\section{REFERENCES}

1. Bager B. Perinatally acquired brachial plexus palsy-a persisting challenge. Acta Paediatr 1997;86(11):1214-9. [CrossRef]

2. DiTaranto P, Campagna L, Price AE, Grossman JAl. Outcome Following Nonoperative Treatment of Brachial Plexus Birth Injuries. J Child Neurol 2004;19(2):87-90. [CrossRef]

3. Brown T, Cupido C, Scarfone H, Pape K, Galea V, McComas A. Developmental apraxia arising from neonatal brachial plexus palsy. Neurology 2000;55(1):24-30. [CrossRef]

4. Annika J, Paul U, Anna-Lena L. Obstetric brachial plexus palsy - A prospective, population-based study of incidence, recovery, and long-term residual impairment at 10 to 12 years of age. Eur J Paediatr Neurol 2019;23(1):87-93. [CrossRef]

5. Pondaag W, Malessy MJA. Evidence that nerve surgery improves functional outcome for obstetric brachial plexus injury. J Hand Surg Eur Vol 2021;46(3):229-36. [CrossRef]

6. Oberlin C. Rethinking surgical strategy in the management of obstetrical palsy. J Hand Surg Eur Vol 2021;46(7):705-7. [CrossRef]

7. Vekris MD, Beris $A E$, Lykissas MG, Korompilias AV, Vekris $A D$, Soucacos PN. Restoration of elbow function in severe brachial plexus paralysis via muscle transfers. Injury 2008;39(3):15-22. [CrossRef]

8. Coulet B, Chammas M. Palsy of elbow extension. Hand Surg Rehabil 2021;S2468-1229(21)00243-7.

9. Vekris MD, Papadopoulos DV, Gelalis ID, Kontogeorgakos V, Tsantes AG, Gkiatas I, et al. Secondary procedures for restoration of upper limb function in late cases of neonatal brachial plexus palsy. Eur J Orthop Surg Traumatol 2019;29(2):329-36. [CrossRef]
10. Ejeskär A. Elbow extension. Hand Clinics 2002;18(3):449-59. [CrossRef]

11. Friedenberg ZB. Transposition of the biceps brachii for triceps weakness. J Bone Joint Surg Am 1954;36-A(3):656-8. [CrossRef]

12. Moberg E. Surgical treatment for absent single-hand grip and elbow extension in quadriplegia. Principles and preliminary experience. J Bone Joint Surg Am 1975;57(2):196-206. [CrossRef]

13. Bertelli JA. Lower Trapezius Muscle Transfer for Reconstruction of Elbow Extension in Brachial Plexus Injuries. J Hand Surg Eur Vol 2009;34(4):459-64. [CrossRef]

14. Ozkan T, Okumus A, Aydin A, Ozkan S, Tuncer S. Brachioradialis Transposition for Elbow Extension in Obstetrical Brachial Plexus Palsy. Techniques in Hand and Upper Extremity Surgery 2005;9(1):60-5. [CrossRef]

15. Leonello DT, Galley IJ, Bain GI, Carter CD. Brachialis Muscle Anatomy. J Bone Joint Surg Am 2007;89(6):1293-7. [CrossRef]

16. Chuang DC, Hattori Y, Ma And HS, Chen HC. The Reconstructive Strategy for Improving Elbow Function in Late Obstetric Brachial Plexus Palsy. Plast Reconstr Surg 2002;109(1):116-26. [CrossRef]

17. Terzis JK, Vekris MD, Soucacos PN. Outcomes of Brachial Plexus Reconstruction in 204 Patients with Devastating Paralysis. Plast Reconstr Surg 1999;104(5):1221-40. [CrossRef]

18. Jones BN, Manske PR, Schoenecker PL, Dailey L. Latissimus Dorsi Transfer to Restore Elbow Extension in Obstetrical Palsy. J Pediatr Orthop 1985;5(3):287-9. [CrossRef]

19. Doi K, Sakai K, Fuchigami Y, Kawai S. Reconstruction of irreparable brachial plexus injuries with reinnervated freemuscle transfer. J Neurosurg 1996;85(1):174-7. [CrossRef]

20. Bertelli JA. Brachialis Muscle Transfer to the Forearm Muscles in Obstetric Brachial Plexus Palsy. J Hand Surg Br 2006;31(3):261-5. [CrossRef]

21. Murray WM, Buchanan TS, Delp SL. The isometric functional capacity of muscles that cross the elbow. J Biomech 2000;33(8):943-52. [CrossRef]

22. Ozkan T, Aydin A, Onel D, Ozkan S. [Reconstruction of shoulder abduction and external rotation in obstetric brachial plexus palsy]. Acta Orthop Traumatol Turc 2004;38(3):161-9 